\title{
Conscience should guide doctors at end of life
}

A 11 doctors have the right to follow their conscience when deciding whether to assist dying patients physically or to provide them with the means to end their lives - within the bounds of legislation, delegates to the Canadian Medical Association's (CMA's) annual meeting have voted.

As Canada considers changing its laws concerning assisted death, Canada's doctors considered their stance on the second day of the CMA's 147th annual meeting in Ottawa. In the end, they voted $91 \%$ in favour of allowing individual physicians to follow their conscience in deciding whether to provide assistance.

The association's current policy (drafted in 2007) states that physicians should not provide such assistance, but as laws change, most recently Bill 52 in Quebec, CMA decided to revisit its policy. Former CMA president Dr. Louis Hugo Francescutti says General Council's wishes will be discussed by the CMA Board of Directors. "I can't predict what is going to come out of it, but I am hopeful."

CMA's French-language spokesperson Dr. Pierre Harvey explained that it's not up to physicians to take a stance for or against the issue; that's the responsibility of society. However, physicians can say what they want to do. "The motion was inspired by respect for our diversity," he said.

The motion represents major progress over last year, when delegates at the annual meeting couldn't even agree on terminology. In the intervening months, CMA hosted a series of town hall meetings across Canada on the topic. "The town halls galvanized our view around this," said Francescutti.

The terminology was changed to physician-assisted death at this year's meeting, and doctors were encouraged to voice their views during a nearly three-hour session. The complex ethical issue involves the physician's ability to meet terminal patients' requests to end

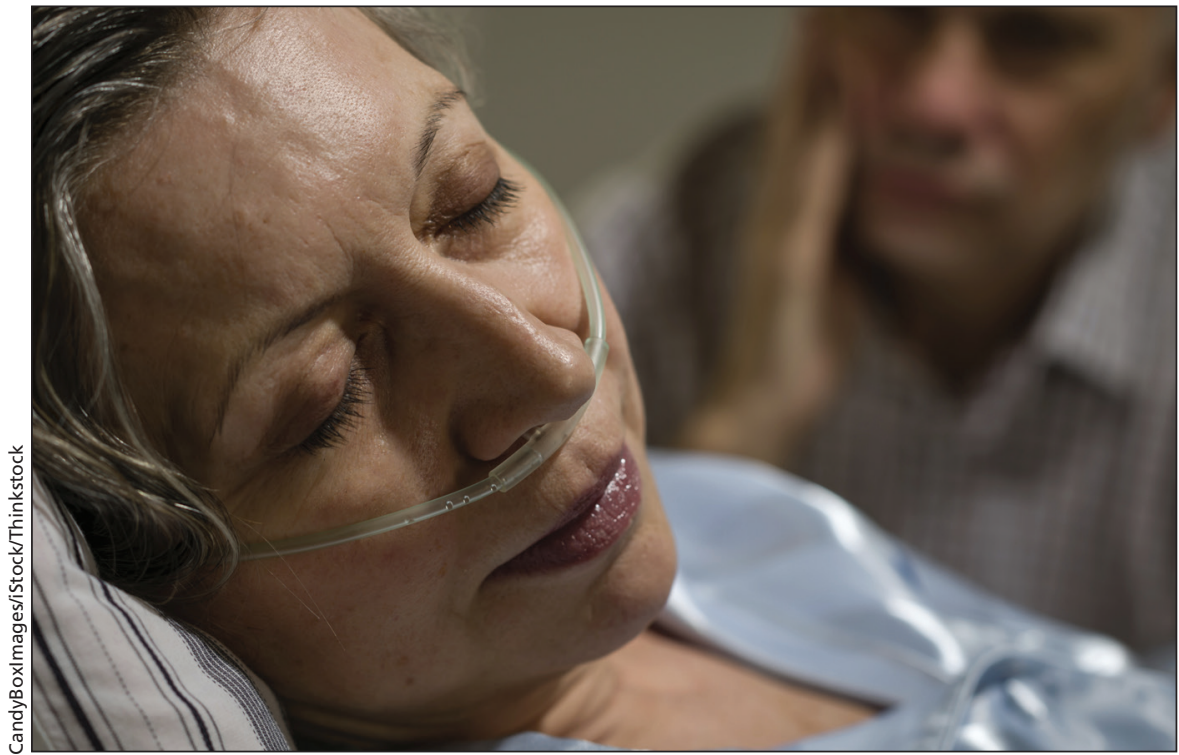

As Canada considers changes to its laws on assisted death, CMA decided it was time to revisit its policy.

their suffering or expected loss of control; the effectiveness of and access to palliative care; and their own legal liabilities and responsibilities.

Canadians need better, more equitable access to palliative care, doctors agreed. But even a national strategy and better access to pain relief will not negate the need for medical aid in dying, many doctors concluded.

For some patients, doctors who provide morphine and sedatives are not only giving pain relief, "we are actively facilitating their death," said Dr. Paul Parks, an emergency physician from Medicine Hat, Alberta.

The stories doctors related on Aug. 19 were as personal as they were professional. They acknowledged the often agonizing dilemmas patients, their families and their doctors face.

Dr. Sarah Bates, a Calgary family doctor, addressed delegates as a caregiver and potential future patient, she said. "My Mom developed familial Alzheimer's in her early 50s. My sister has just been diagnosed - she is 43 . So these issues weigh very heavily on my mind," Bates told about 250 delegates and close to 400 observers.
"There are conditions, we all know, where no level of oxygen, morphine or supportive counselling is going to provide relief of suffering. Just because we have a respiratory drive, a swallowing reflex and a beating heart doesn't mean we have a life."

CMA is discussing the issue of endof-life care in the context of an upcoming Supreme Court of Canada decision that is expected to rule in October on the legality of physician-assisted death. CMA has been granted status to intervene as a "friend of the court" in the case, and will be presenting the complexities of these issues from doctors' perspectives, Dr. Jeff Blackmer, the association's executive director of ethics, professionalism and international affairs, told delegates.

Quebec has passed legislation permitting medical aid in dying, under particular circumstances and after consultation with more than one doctor. That law is expected to take effect in late 2015 unless it is the subject of a federal constitutional challenge.

The bill may well make Dr. Angela Genge, who heads the Montréal Neurological Institute's amyotrophic lateral 
sclerosis (ALS) clinic, the first doctor in Quebec asked to comply with the law. That's because her patients with ALS and other terminal neurodegenerative diseases regularly ask her to help them end their lives.

"My ALS patients are very bright," Genge told delegates. "They can be any one of you in the room." Her patients fear loss of control, suffering, and being a burden on their families. Most of all, they want permission to discuss how and when they want to die.

Every patient has the right to have that discussion, Genge said, and Quebec's law provides clarity around that right and ensures it can take place, even if it doesn't alter how a doctor responds to these requests.

"The minute I do not allow my patient to discuss their desire to be in control of their death, I actually break the patient-physician relationship," she added. "My patients are as intelligent as you and I are and they have the right to have that discussion."

All of her patients have, however, ultimately "changed the goalposts" they initially set for themselves about what point in their illness they would choose to end their lives. That's the reason Genge hopes the regulations that accompany the Quebec legislation will not fix a time period in which physicians have to respond to a patient's request for help ending his or her life.

In addition to passing a motion supporting physicians' right to act according to their conscience, the delegates also instructed CMA to investigate and communicate Inuit, Métis and First Nations' perspectives on euthanasia, physician-assisted death and end-of-life care. Physicians must be sensitive to the experience of many Aboriginal communities already coping with high levels of suicide, and in particular teen suicide, Dr. David Pontin, the president of the Northwest Territories Medical Association, pointed out.

It is also critical that CMA develop a strategy to make sure there are enough doctors trained to deliver palliative care across Canada. Currently, Canada needs at least another 300 palliative care specialists, Dr. Doris Barwich of the
Canadian Society of Palliative Care Physicians told delegates. In addition, $75 \%$ of doctors have identified their need for further palliative care help and education, she added.

Other family physicians, however, described their current cradle-to-grave practices involving palliative care and suggested that with greater education and support, more doctors could provide these services that Canadians have repeatedly stated they want and need.

"All doctors want is a little bit of help, mostly around prescribing narcotics," said Dr. Suzanne Strasberg, a family physician in Toronto. "What we need is: we need education. I think we should be ready to do this work."

CMA will support the development of an advanced care planning, palliative and end-of-life care strategy in all provinces and territories, delegates agreed, while leaving it to the broader Canadian public and legislators to change the laws around medical aid in dying. — Laura Eggertson, Ottawa, Ont.

CMAJ 2014. DOI:10.1503/cmaj.109-4880 